\title{
Snapshots of the Greenland ice sheet configuration in the Pliocene to early Pleistocene
}

\author{
Anne M. SOLGAARD, ${ }^{1,2}$ Niels REEH,${ }^{3 \dagger}$ Peter JAPSEN, ${ }^{1}$ Tove NIELSEN ${ }^{1}$ \\ ${ }^{1}$ Geological Survey of Denmark and Greenland, Øster Voldgade 10, DK-1350 Copenhagen, Denmark \\ E-mail: solgaard@gfy.ku.dk \\ ${ }^{2}$ Centre for Ice and Climate, Niels Bohr Institute, University of Copenhagen, Juliane Maries Vej 30, \\ DK-2100 Copenhagen, Denmark \\ ${ }^{3}$ DTU Space, National Space Institute, Technical University of Denmark, Building 348, Ørsteds Plads, \\ DK-2800 Kgs. Lyngby, Denmark
}

\begin{abstract}
The geometry of the ice sheets during the Pliocene to early Pleistocene is not well constrained. Here we apply an ice-flow model in the study of the Greenland ice sheet (GIS) during three extreme intervals of this period constrained by geological observations and climate reconstructions. We study the extent of the GIS during the Mid-Pliocene Warmth (3.3-3.0Ma), its advance across the continental shelf during the late Pliocene to early Pleistocene glaciations (3.0-2.4 Ma) as implied by offshore geological studies, and the transition from glacial to interglacial conditions around $2.4 \mathrm{Ma}$ as deduced from the deposits of the Kap København Formation, North Greenland. Our experiments show that no coherent ice sheet is likely to have existed in Greenland during the Mid-Pliocene Warmth and that only local ice caps may have been present in the coastal mountains of East Greenland. Our results illustrate the variability of the GIS during the Pliocene to early Pleistocene and underline the importance of including independent estimates of the GIS in studies of climate during this period. We conclude that the GIS did not exist throughout the Pliocene to early Pleistocene, and that it melted during interglacials even during the late Pliocene climate deterioration.
\end{abstract}

\section{INTRODUCTION}

The Pliocene (5.3-2.6Ma) is the most recent time when global temperatures were generally warmer than at present for a sustained period (Hill and others, 2008), and furthermore, the continents had nearly reached their present positions. These conditions make the Pliocene an important analogue for studies of the dynamics of climate under warmer conditions than today. A short interval during the Pliocene, the Mid-Pliocene Warmth, when both temperature and $\mathrm{CO}_{2}$ levels were higher than pre-industrial, is consequently described in the Intergovernmental Panel on Climate Change (IPCC) Fourth Assessment Report as a possible analogue to future climate (Jansen and others, 2007).

Ice sheets are important parts of the global climate system, but there have been only a few studies (e.g. Lunt and others, 2008, 2009) of the geometry of the Earth's major ice sheets (e.g. the Greenland ice sheet (GIS)) during the Pliocene and early Pleistocene. The development of the GIS before the Last Interglacial can only be traced from geological observations, because the oldest dated ice core from the GIS is $123 \mathrm{ka}$ old (NorthGRIP members, 2004). It is thus a matter of debate to what extent the GIS existed prior to the Quaternary glaciations (e.g. during the Pliocene). Lunt and others (2008) found that 'some ice' existed on Greenland before the onset of extensive glaciations, and Lunt and others (2009) that the mid-Pliocene GIS was much reduced relative to the present based on numerical modelling. Larsen and others (1994) used material from offshore drill cores to conclude that 'full glacial conditions' were established in southeast Greenland at $7 \mathrm{Ma}$. However, Willerslev and others (2007) studied biomolecules from the silty section

${ }^{\dagger}$ Deceased. at the base of deep ice cores in Greenland and found that central southern Greenland was forested 'within the past million years' (see Fig. 1).

In this paper, we use an ice-flow model to study steady states of the GIS constrained by climate data based on geological observations. We focus our modelling on snapshots of the development during the Pliocene to early Pleistocene in time intervals where reliable climate proxies are available from the geological record in Greenland, rather than relying on climate output from general circulation models (GCMs). This period represents a wide range of climatic conditions that allows us to test various scenarios. Haywood and others (2009) subdivided the Pliocene into three periods: (1) an early Pliocene warm period, (2) the Mid-Pliocene Warmth (3.3-3.0 Ma) and (3) a climatic deterioration during the late Pliocene leading to the highmagnitude climate variability of the Pleistocene, characterized by waxing and waning of Northern Hemisphere ice sheets. We chose to study the GIS during three extreme climatic periods of the Pliocene to early Pleistocene:

the Mid-Pliocene Warmth (MPW) snapshot equivalent to period 2 of Haywood and others (2009)

the Pliocene Glaciation (PG) snapshot (3.0-2.4 Ma) representing a glacial period following the Mid-Pliocene Warmth (e.g. the Praetiglian) when ice advanced across the continental shelf (e.g. Solheim and others, 1998; Thiede and others, 1998)

the early Pleistocene Kap København (KK) snapshot (2.4 Ma) corresponding to the transition from the full glacial conditions of the PG snapshot to a warm and almost ice-free Greenland (e.g. Funder and others, 2001), 




Fig. 1. Present-day Greenland in the $20 \mathrm{~km} \times 20 \mathrm{~km}$ resolution used in the ice-flow model. Kap København marks the location of the early Pliocene interglacial deposits of the Kap København Formation, and Dye-3 marks the location of the silty section at the base of deep ice cores studied by Willerslev and others (2007). White: land ice; brown: ice-free land; light blue: shelf waters; dark blue: ocean beyond the shelf break.

where the PG and KK snapshots are examples of the great variability of the late Pliocene to early Pleistocene climate, equivalent to period 3 of Haywood and others (2009).

Earlier studies of the GIS during the Pliocene have used output from GCMs to force an ice-flow model (e.g. Lunt and others, 2008, 2009). Here we apply previous reconstructions of temperature, precipitation and ice extent from palaeoproxies and results from GCM studies to model the extent of the Pliocene GIS. The advance of the ice sheet on the continental shelf as well as the transition from glacial to interglacial conditions at $2.4 \mathrm{Ma}$ has not previously been investigated using ice-flow modelling.

\section{GEOLOGICAL CONSTRAINTS ON THE ICE-SHEET MODELLING}

\section{Mid-Pliocene warmth}

The Mid-Pliocene Warmth was a period when average climate conditions differed distinctly from those in the periods surrounding it (Dowsett and others, 1999). A reconstruction of the mid-Pliocene climate is provided by the Pliocene, Research, Interpretation, and Synoptic Mapping (PRISM) project (Dowsett and others, 1994, 1999,
2010) based on many different proxies from the geological record. The reconstruction indicates a sea level $25 \mathrm{~m}$ higher than today, reduced sea-ice coverage, reduced land-ice volume, increased sea surface temperatures at high latitudes, expansion of evergreen forest to the Arctic Ocean, and essential elimination of polar desert and tundra regions in the Northern Hemisphere. In particular, the GIS and the Antarctic ice sheets are found to be reduced by $50 \%$ and $25 \%$, respectively, and all other land ice to be removed.

The PRISM dataset does not provide maps of land surface temperatures, but from the vegetation reconstruction by Salzmann and others (2008) for the mid-Pliocene it is possible to get an idea of the climatic conditions in Greenland. This model combines vegetation reconstruction from palaeobotanical proxies from 202 terrestrial and marine sites with numerical simulations and is part of the newest PRISM dataset, PRISM3. Greenland has exceptionally low data coverage, and this part of the reconstruction relies mostly on numerical modelling results. In general, the reconstruction shows a globally warmer and moister climate, and for Greenland the southern part has forest/taiga along the coast whereas the central part has grasslands. The northern part is covered by tundra while the taiga extends as far north as $80^{\circ} \mathrm{N}$ in the coastal areas. Simulations predict the GIS to be present north of $\sim 75^{\circ} \mathrm{N}$ and to reach elevations of $2400 \mathrm{~m}$ (Sohl and others, 2009).

\section{Pliocene glaciation}

The Northern Hemisphere experienced climatic deterioration, with initial tidewater glaciers, already in the late Oligocene (34 Ma) as inferred from ice-rafted debris (Eldrett and others, 2009). During the early Pliocene, grounded glaciers reached the East Greenland continental shelf (Solheim and others, 1998); however, significant ice-volume increase in the Northern Hemisphere only occurred during the late Pliocene to early Pleistocene (Thiede and others, 1998; Kleiven and others, 2002; Mudelsee and Raymo, 2005). The glaciation of the Greenland continental shelves continued repeatedly throughout the Pliocene to early Pleistocene (Larsen and others 1994; Clausen, 1998; Lykke-Andersen and others, 1998; Nielsen and others, 2005). Possible driving mechanisms for this glacial intensification are discussed by, among others, Japsen and others (2006) and Lunt and others (2008).

The repeated glaciations of the Greenland continental shelves resulted in a large seaward progradation of the shelf edge during the Pliocene to early Pleistocene. The dominant glacial depositional feature is large shelf prograding sedimentary wedges that were built up by ice sheets reaching the shelf edge (Fig. 2). The present-day shelf edge thus marks the maximum extension of grounding ice sheets around Greenland. The largest glacial sedimentary wedges are found in areas where ice streams or outlet glaciers have occurred. Position and paths of palaeo-ice streams are marked by shelf-transverse seabed troughs (Stokes and Clark, 2001) and a broad shelf with a convex outline.

\section{Kap København}

A detailed picture of early Pleistocene, glacial conditions in high-arctic Greenland has been provided by studies of the Kap København Formation (Funder and others, 2001). This is a sequence of sediments that piled up during sealevel rise in an estuarine environment close to the northern tip of Greenland. The sedimentary succession registers the 


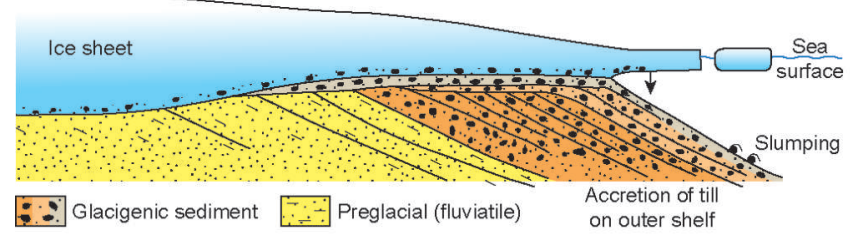

b

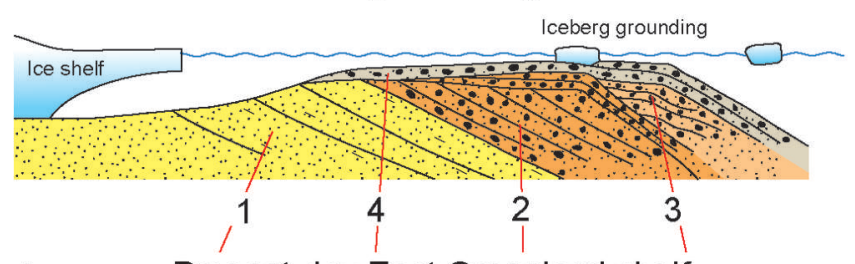

c Present-day East Greenland shelf



Fig. 2. Glacial development of the Greenland shelf. (a, b) Generalized model for development of a glaciated continental margin during (a) maximum glacial conditions with ice reaching the shelf edge, and (b) interglacial periods with an ice-free shelf (after Hambrey and others, 1992). (c) Seismic line illustrating the presentday (interglacial) setting of the East Greenland shelf off Scoresby Sund (see Fig. 1). Here, as on most of the shelves surrounding Greenland, the seismic profile shows the same depositional pattern as in (b): 1. preglacial deposits; 2, 3. Pliocene to early Pleistocene maximum glaciation deposits; 4. late Pleistocene maximum glaciation deposits with iceberg disturbances (base marked by yellow line).

development of an interglacial, from retreat of the ice sheet until the optimum of interglacial warmth. From the surrounding land, a multitude of plant and insect remains were washed into a coastal embayment, mixed with shallow marine micro- and macrofauna, and imbedded and preserved in permafrost until the present. Since almost all the organisms are extant, a comparison with their present demands gives a precise description of environmental parameters at the maximum of interglacial warmth (Table 1).

At this time, trees were growing in lowland North Greenland, but they were small and slow-growing (Bennike, 1990). This indicates that the area was close to the forest ecotone, which today generally follows the $10^{\circ} \mathrm{C}$ July mean temperature. The coldest-month mean temperature, $-17^{\circ} \mathrm{C}$, is derived from the presence of such evergreens as Thuja which are sensitive to cold winters (Bennike, 1990). This combination of winter and summer temperatures indicates annual mean temperatures at $\sim-4^{\circ} \mathrm{C}$, sufficiently low to preserve permafrost in the lowland areas. The Kap København Formation has been referred to isotope stage 96 $(\sim 2.4 \mathrm{Ma})$ by a combination of biostratigraphy, palaeomagnetism and cyclostratigraphy (Funder and others 2001). The estimated deposition time of the Kap København Formation is $20 \mathrm{ka}$, covering the transition of the melting of the Praetiglian ice sheets to the beginning of the Tiglian A interglacial (Funder and others, 2001).

Funder and others (2001) used these temperatures at the northern tip of Greenland in comparison with the present pattern of temperatures in Greenland and lapse rate, to suggest that Greenland at the time of the Kap København Formation was without an ice sheet, with only local ice caps on high mountains in East Greenland. The absence of the GIS was accompanied by a sea-level high stand, which has also been recorded in Alaska where the Fishcreekian sediments contain evidence of warm marine conditions and high sea level (Miller and others, 2010).

Bennike and others (2010) suggested that the upper part of the Kap København Formation was of early Pleistocene age (slightly older than $2 \mathrm{Ma}$ ) whereas its lower part was of late Pliocene age $(\sim 2.6 \mathrm{Ma})$. The palaeo-environmental indicators of the Kap København Formation are, however, unchanged and we will use them to exemplify the transition from glacial to interglacial conditions in the early Pleistocene as described by Funder and others (2001)

\section{MODEL}

The ice-flow model applied is the three-dimensional (3-D), thermomechanical Parallel Ice Sheet Model (PISM) (Bueler and Brown, 2009; user's manual available at http:// www.pism-docs.org). The dynamics are described by the shallow-ice approximation (SIA) equations (Fowler and Larson, 1980; Hutter, 1983) and we assume that the ice does not slide over the bedrock. The isostatic response of the bedrock to changes in ice load is treated by a two-layer model based on Lingle and Clark (1985) and assumes both an elastic and viscous displacement and features modeindependent relaxation times (Bueler and others, 2007). In the PG snapshot the ice sheet expands beyond the present Greenland coastline, and the topography of the present-day shelf is obtained from the International Bathymetric Chart of the Arctic Ocean (IBCAO) by Jakobsson and others (2008). The data are available on a $2 \mathrm{~km} \times 2 \mathrm{~km}$ grid and were resampled to the $20 \mathrm{~km} \times 20 \mathrm{~km}$ grid used in this study. The

Table 1. Early Pleistocene climate during the climate optimum of the Kap København compared to the present. Based on Funder and others (2001)

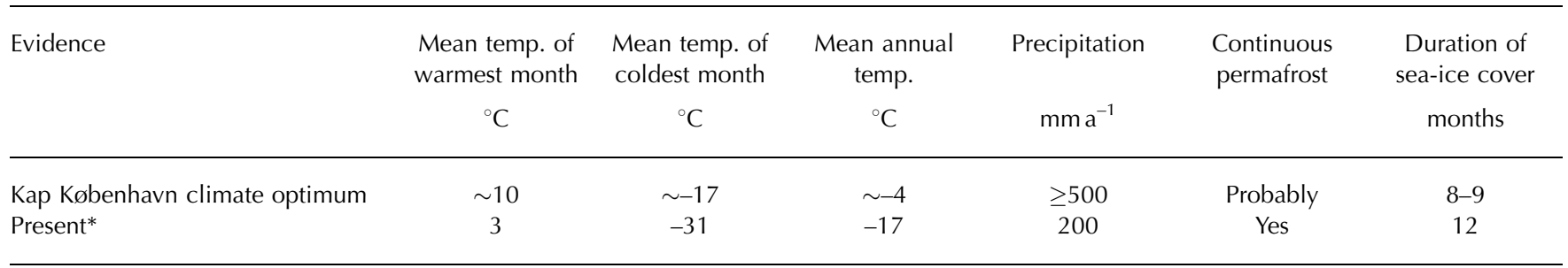

*1961-90 at Nord, $115 \mathrm{~km}$ southeast of Kap København (Danish Meteorological Institute in 2001). 
IBCAO map contains data of the surface of Greenland, but not of the topography beneath the ice sheet. The basal topography is obtained by subtracting the ice thickness by Letréguilly and others (1991) from the IBCAO data.

The mass balance is treated by determining the accumulation rate and ablation rate separately. Ablation is calculated using the degree-day model by Reeh (1991). This has the advantage of using only mean annual and July temperatures as input to describe the annual temperature cycle. Here we use the parameterization of present-day Greenland surface temperatures by Reeh (1991) which uses elevation and latitude as input. The temperature in a gridpoint therefore responds to the surface elevation changes of the ice sheet or ice-free bedrock. The input of accumulation is the precipitation map by Calanca and others (2000). We look at the GIS under both warmer and colder conditions than at present. We account for this by adding the change compared to the present in mean annual temperature, $\Delta T_{\text {Annual, }}$ and in July temperature, $\Delta T_{\text {July, }}$ to the present-day temperature-parameterization in each gridpoint. $\Delta T_{\text {Annual }}$ and $\Delta T_{\text {July }}$ are assumed to be uniform over the entire grid. We let the accumulation rate vary in response to temperature change after Letréguilly and others (1991):

$$
\operatorname{acc}\left(\Delta T_{\text {Annual }}\right)=\operatorname{acc}(0) \cdot 1.0533^{\Delta T_{\text {Annual }}},
$$

where $\operatorname{acc}(0)$ is the present accumulation rate. This implies a change of $5.3 \%$ in accumulation rate for every $1{ }^{\circ} \mathrm{C}$ change in mean annual temperature. Not all precipitation falls as snow as temperature increases, and we account for this by calculating the fraction of rain following Marsiat (1994) and let it run off immediately.

In the standard version of PISM, the ice is removed when it reaches the coastline. However, in some periods of the Pliocene the ice sheet extended beyond the coastline onto the continental shelves. To accommodate this behaviour within our model set-up, we changed the parameterization in all our experiments so that calving does not occur before the ice reaches the present-day shelf break, which we define as being at the $\sim 500 \mathrm{~m}$ water-depth contour. Similar parameterizations using a critical water depth as calving criterion have been used to model the marine extent of ice sheets (e.g. Zweck and Huybrechts, 2005). Our parameterization is thus similar to having a sea level $500 \mathrm{~m}$ lower than today.

The mass balance (accumulation minus ablation) is set to zero where there is no ice and the bedrock topography is below zero (as outside the present coastline), thus preventing ice from being created without having contact with the expanding ice sheet. The precipitation map by Calanca and others (2000) does not extend beyond the present-day Greenland coastline. This experiment requires accumulation in the shelf areas, and the precipitation map is extended in a simplistic way by letting the values at the coast extend horizontally to the edge of the grid.

When simulating the present-day GIS, the model gives a reasonable result. We run to steady state using the above temperature parameterization and accumulation map and let the ice calve off at the present coastline. The resulting ice sheet has a volume $16 \%$ larger than observed: the interior parts are flatter and the margin areas thicker. This is partly due to the lack of higher-order stresses in a SIA model. The ice-covered area is similar to that at the present. The largest difference in ice extent is in North Greenland where the simulated ice sheet extends further into Peary Land (though not covering it) than observed.

\section{EXPERIMENTS}

The three time slices (MPW, PG and KK) and the associated experiments are described in the following and summarized in Table 2; the results are illustrated by Figures 3-6. All experiments are run for $100 \mathrm{ka}$, allowing the ice sheet to reach steady state in all experiments.

\section{Mid-Pliocene warmth}

The PRISM dataset has been used as boundary conditions in several GCM studies (e.g. Haywood and Valdes, 2004; Jiang and others, 2005; Lunt and others, 2008, 2009, 2010), and all studies found increases in mean global temperature and precipitation compared with the present. Jiang and others (2005) showed a $4.8^{\circ} \mathrm{C}$ increase in mean annual temperature at $60-90^{\circ} \mathrm{N}$, and a $6-12^{\circ} \mathrm{C}$ increase of in summer temperature for Greenland. Part of the temperature increase is caused by a change in ice-sheet elevation between the present and Pliocene ice-sheet configurations used in the GCMs. Taking this into account, the summer warming is at least $1-7^{\circ} \mathrm{C}$ (assuming a lapse rate of $0.7^{\circ} \mathrm{C}(100 \mathrm{~m})^{-1}$ and a lowering of $700 \mathrm{~m}$ on average). A figure in Haywood and Valdes (2004) shows summer temperatures over Greenland that are $10-15^{\circ} \mathrm{C}$ higher than at present. This corresponds to $\sim 5-10^{\circ} \mathrm{C}$ after taking into account the elevation difference. Lunt and others (2010) presented a plot of simulated, mean annual temperature change that showed a $9-10^{\circ} \mathrm{C}$ warming over Greenland compared to the present. Again, after taking into account the elevation difference this amounts to at least $4-5^{\circ} \mathrm{C}$.

In the MPW snapshot, we use $\Delta T_{\text {Annual }}=5^{\circ} \mathrm{C}$, which is the general value from the GCM experiments described above, and $\Delta T_{\text {July }}=6,5,4,3^{\circ} \mathrm{C}$ which is at the middle to higher end of the results of Jiang and others (2005) after taking into account elevation differences, but at the lower end of the results of Haywood and Valdes (2004). Using $\Delta T_{\text {Annual }}=5^{\circ} \mathrm{C}$ in Equation (1) results in a $30 \%$ precipitation increase compared with the present. This is very similar to the result of $128 \%$ of present precipitation obtained by Jiang and others (2005) for terrestrial precipitation at $60-90^{\circ} \mathrm{N}$ for the midPliocene. The MPW experiments are started from no ice and bedrock after isostatic rebound. A set of sensitivity experiments are also performed with the same set of temperatures, but with simulations starting from the present-day ice-sheet configuration instead of ice-free conditions.

\section{Pliocene glaciation}

The aim of the PG snapshot is to model the flow of the ice sheet onto the continental shelf. As described earlier, the ice advanced across the shelf during the Pliocene to early Pleistocene (Solheim and others, 1998; Nielsen and others, 2005).

All experiments in this scenario are started from no ice and bedrock after isostatic rebound. The temperature decrease is assumed to be uniform over the year $(\Delta T=$ $\left.\Delta T_{\text {Annual }}=\Delta T_{\text {July }}\right)$. The 14 experiments for this scenario use a temperature decrease of $0-13^{\circ} \mathrm{C}$.

\section{Kap København}

In the KK experiments we model the transition from the Praetiglian ice sheets to the following Tiglian A interglacial (Funder and others, 2001).

During the climatic optimum of the Kap København Formation, the temperature of the warmest month as 
Table 2. List of the sub-experiments of each time slice

\begin{tabular}{|c|c|c|c|c|c|}
\hline \multirow[t]{3}{*}{ Experiment } & \multicolumn{2}{|c|}{ Temp. increase compared to present } & \multirow{3}{*}{$\begin{array}{l}\text { Precip. compared to } \\
\text { present } \\
\\
\%\end{array}$} & \multirow[t]{3}{*}{ Initial ice sheet } & \multirow{3}{*}{$\begin{array}{l}\text { Steady-state ice volume } \\
\qquad 10^{6} \mathrm{~km}^{3}\end{array}$} \\
\hline & $\Delta T_{\text {July }}$ & $\Delta T_{\text {Annual }}$ & & & \\
\hline & ${ }^{\circ} \mathrm{C}$ & ${ }^{\circ} \mathrm{C}$ & & & \\
\hline \multicolumn{6}{|c|}{ Mid-Pliocene Warmth } \\
\hline MPW1 & 4 & 5 & 130 & Ice-free & 0.1 \\
\hline MPW2 & 5 & 5 & 130 & Ice-free & 0.1 \\
\hline MPW3 & 6 & 5 & 130 & Ice-free & 0.0 \\
\hline MPW4 & 3 & 5 & 130 & Ice-free & 0.2 \\
\hline MPW1b & 4 & 5 & 130 & Present-day & 0.2 \\
\hline MPW2b & 5 & 5 & 130 & Present-day & 0.1 \\
\hline MPW3b & 6 & 5 & 130 & Present-day & 0.1 \\
\hline MPW4b & 3 & 5 & 130 & Present-day & 2.2 \\
\hline \multicolumn{6}{|c|}{ Pliocene Glaciation } \\
\hline PG1 & -1 & -1 & 95 & Ice-free & 3.8 \\
\hline PG2 & -2 & -2 & 90 & Ice-free & 4.1 \\
\hline PG3 & -3 & -3 & 86 & Ice-free & 4.2 \\
\hline PG4 & -4 & -4 & 81 & Ice-free & 4.5 \\
\hline PG5 & -5 & -5 & 77 & Ice-free & 4.7 \\
\hline PG6 & -6 & -6 & 73 & Ice-free & 5.0 \\
\hline PG7 & -7 & -7 & 70 & Ice-free & 5.1 \\
\hline PG8 & -8 & -8 & 66 & Ice-free & 5.3 \\
\hline PG9 & -9 & -9 & 63 & Ice-free & 5.4 \\
\hline PG10 & -10 & -10 & 59 & Ice-free & 5.5 \\
\hline PG11 & -11 & -11 & 56 & Ice-free & 5.5 \\
\hline PG12 & -12 & -12 & 54 & Ice-free & 5.5 \\
\hline PG13 & -13 & -13 & 51 & Ice-free & 5.6 \\
\hline \multicolumn{6}{|c|}{ Kap København } \\
\hline KK1 & 5 & 13 & 196 & PG13 & 0.1 \\
\hline KK2 & 6 & 13 & 196 & PG13 & 0.1 \\
\hline KK3 & 7 & 13 & 196 & PG13 & 0.0 \\
\hline KK4 & 4 & 13 & 196 & PG13 & 0.1 \\
\hline KK5 & 3 & 13 & 196 & PG13 & 1.6 \\
\hline $\mathrm{KK} 1 \mathrm{~b}$ & 5 & 13 & 196 & Ice-free & 0.1 \\
\hline $\mathrm{KK} 2 \mathrm{~b}$ & 6 & 13 & 196 & Ice-free & 0.0 \\
\hline KK3b & 7 & 13 & 196 & Ice-free & 0.0 \\
\hline
\end{tabular}

estimated by Funder and others (2001) was $\sim 10^{\circ} \mathrm{C}$, which is $\sim 7^{\circ} \mathrm{C}$ higher than today, based on studies of insects and vegetation. Likewise, the temperature of the coldest month is thought to have been $\sim 14^{\circ} \mathrm{C}$ higher than today. The estimated mean annual temperature is $\sim-4^{\circ} \mathrm{C}$, which is $\sim 13^{\circ} \mathrm{C}$ higher than today. The plants and insects found at Kap København indicate that precipitation was $150 \%$ of the present value, and the duration of sea-ice cover is thought to have been 8-9 months compared to the present 12 months (Funder and others, 2001).

In the $\mathrm{KK}$ snapshot, all runs use $\Delta T_{\text {Annual }}=13^{\circ} \mathrm{C}$ and are started from the glacial ice-sheet configuration resulting from PG13 $\left(\Delta T=-13^{\circ} \mathrm{C}\right)$ in order to model the glacialinterglacial transition. The five experiments use $\Delta T_{\text {July }}=3,4$, 5,6 and $7^{\circ} \mathrm{C}$. In order to test the sensitivity of the results to the initial configuration, three of the experiments were repeated starting from no ice as well.

\section{RESULTS AND DISCUSSION}

\section{Mid-Pliocene warmth}

The results of the four experiments in the MPW snapshot are very similar (see Fig. 3). Greenland is free of ice, except for small amounts in the high coastal mountains of East
Greenland. In the four experiments, we have applied July temperatures $3-6^{\circ} \mathrm{C}$ higher than today, i.e. at the lower end of what is predicted by Haywood and Valdes (2004). If higher summer temperatures were applied, no ice would develop when starting from an ice-free Greenland. The results of our four MPW experiments resemble those of Lunt and others (2009) where the mid-Pliocene GIS is modelled using output from a fully coupled, atmosphere-ocean GCM with respect to the location of ice initiation. Their Pliocene experiment shows coherent ice covering eastern Greenland, whereas ice only exists in the form of small, local ice caps at high elevations in the same area in our results.

In the PRISM reconstruction the volume of the GIS is $\sim 50 \%$ less than the present value. Our experiments give considerably less ice: the steady-state ice sheet of the MPW4 experiment, which results in the largest ice sheet of the four experiments, has only $\sim 7 \%$ of the present volume.

Our results must be considered as a lower bound for the ice volume of the GIS during the mid-Pliocene, as we start all four experiments assuming an ice-free Greenland. Four additional MPW experiments were conducted (Fig. 7; Table 2), in order to investigate the effect of starting from the present-day ice-sheet configuration using the same temperature anomalies as MPW1-4. These results show that a considerable ice sheet remains in the new MPW4b 



Fig. 3. The GIS configuration for three of the four experiments in the MPW snapshot (Table 2): (a) MPW1, (b) MPW2 and (c) MPW4. Note that only the high coastal mountains of East Greenland are glaciated.

experiment, whereas the ice sheet disintegrates completely in MPW1b-MPW3b, leaving only small amounts of ice in the East Greenland coastal mountains. The waste-down takes $<10 \mathrm{ka}$ in MPW1b and MPW2b and <20 ka in MPW3b. A further sensitivity test shows that not before a lowering of $\Delta T_{\text {July }}$ to $2^{\circ} \mathrm{C}$ does a substantial ice mass build

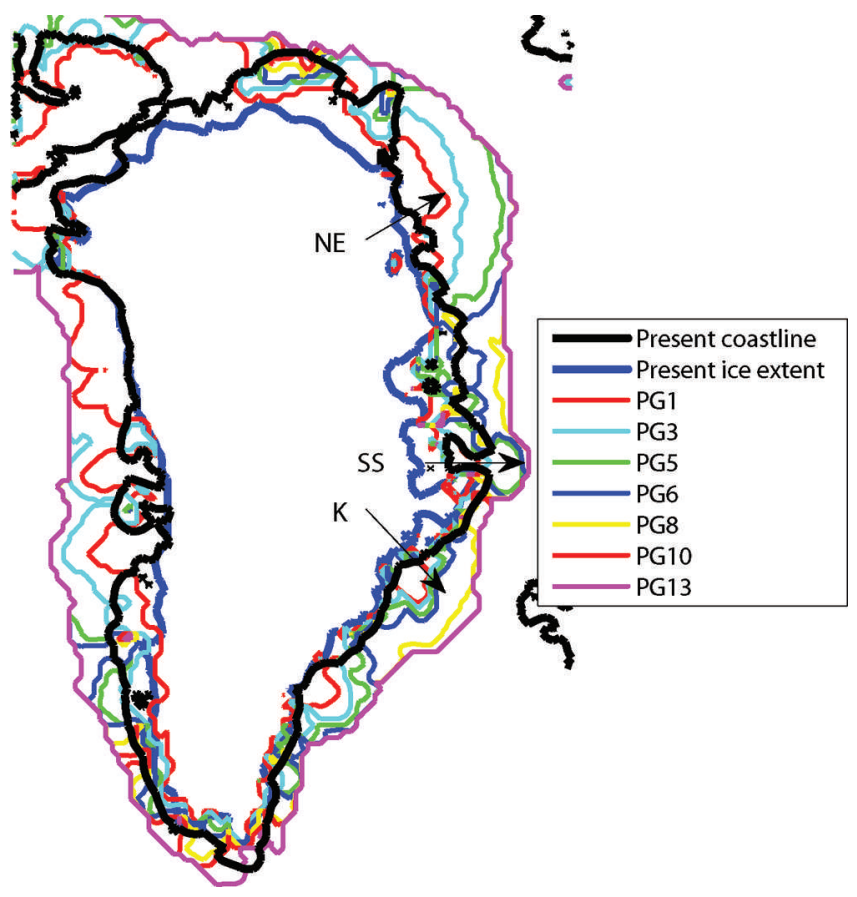

Fig. 4. Ice extents of the PG experiments (not all experiments are shown). The experiments are described in Table 2. NE, SS and K mark the positions of the northeast Greenland, Scoresby Sund and Kangerlussuaq bulges, respectively. Note that the ice-sheet geometry in many of the experiments is not determined by the calving criterion. up from an ice-free Greenland. The result that very little ice existed in Greenland during the Mid-Pliocene Warm period is thus very robust.

\section{Pliocene glaciation}

All steady-state ice sheets of the PG snapshot extend beyond the present coastline and have a larger volume than the present-day GIS (see Figs 4 and 5). PG8-PG13 reach the shelf break in most places; PG13 has the largest extent but the difference from PG8 is not large. The volume is also very similar. For PG1-PG7 the steady-state ice volume increases linearly with the decrease in temperature. In these experiments the ice sheets do not reach the shelf break everywhere due to increased ablation. Their geometry is not determined by the calving criterion in these places.

In experiments PG1-PG7 where ablation constrains the ice sheet behind the shelf break, it is interesting that the ice sheet has bulges in many of the same places as the continental shelf. Despite the lack of higher-order features, the model can reproduce these basic characteristics. In East Greenland these bulges are prominent outside the major glacial outlets (e.g. Scoresby Sund, Kangerlussuaq, and northeast Greenland in the area of Nioghalvfjerdsfjorden glacier and Storstrømmen (see Fig. 5b)). We apply a grid size of $20 \mathrm{~km} \times 20 \mathrm{~km}$, so small-scale topographic forms of the outlet areas are excluded. The accumulation map is extended to the shelf areas in the simplistic way described earlier, where the accumulation rate is constant along horizontal lines. The bulges are therefore not created by the accumulation pattern. This suggests that it is the largescale features of the inland topography that control the advance of the ice sheet onto the shelf.

The shelf break north of Disko Island is the first to be reached by the ice sheet for cooling temperature conditions, while the largest temperature decrease required before the shelf break is reached is on the southern half of the east coast. Ice also expands across Nares Strait into Canada as 

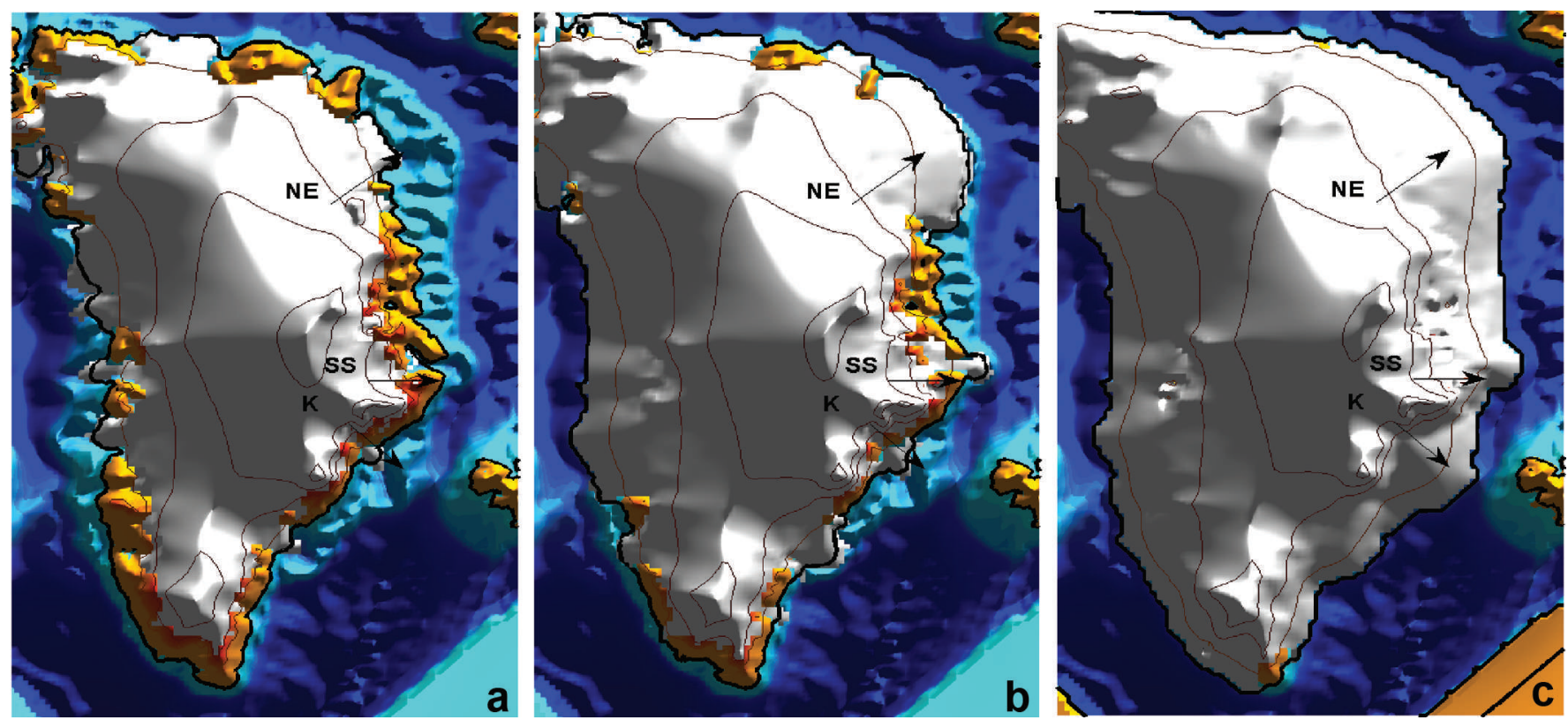

Fig. 5. The GIS configuration for the PG1 (a), PG5 (b) and PG13 (c) experiments in the PG snapshot (Table 2). NE, SS and K mark the position of the northeast Greenland, Scoresby Sund and Kangerlussuaq bulges, respectively. The four contours mark 1000, 2000, 2500 and $3000 \mathrm{~m}$ elevation. Note the bulges of the ice sheet outside the major outlet glaciers in East Greenland in (b). In (c) the ice sheet reaches the shelf break.

during the last ice age (England and others, 2006). As stated earlier, the ice sheet already flows beyond the present-day coastline at temperatures close to present-day conditions (Fig. 5a). This occurs in places where the ice sheet today reaches the coastline and is a result of lowering sea level by $500 \mathrm{~m}$, indicating that these shelf areas would be the first to become glaciated in the case of lower sea level. Assuming a sea level like that of the present day, the modelled ice-sheet extent is also similar to that of the present day.

In many of the PG experiments, grounded ice reaches the shelf break. The bathymetry used is that of the present day, which is formed by millennia of ice advances (e.g. Nielsen and others, 2005). During the Pliocene the continental shelves did not have their current size: Solheim and others (1998) found that the main phase of construction of the Scoresby Sund glacial fan took place during and after the late Pliocene to early Pleistocene. The present-day shelf break is therefore a maximum of shelf extent for our study period. Even under glacial conditions where a considerable amount of ocean water may have been stored on land in ice caps, a lowering of sea level by $500 \mathrm{~m}$ is still substantial. The ice sheet would then have had more difficulty advancing
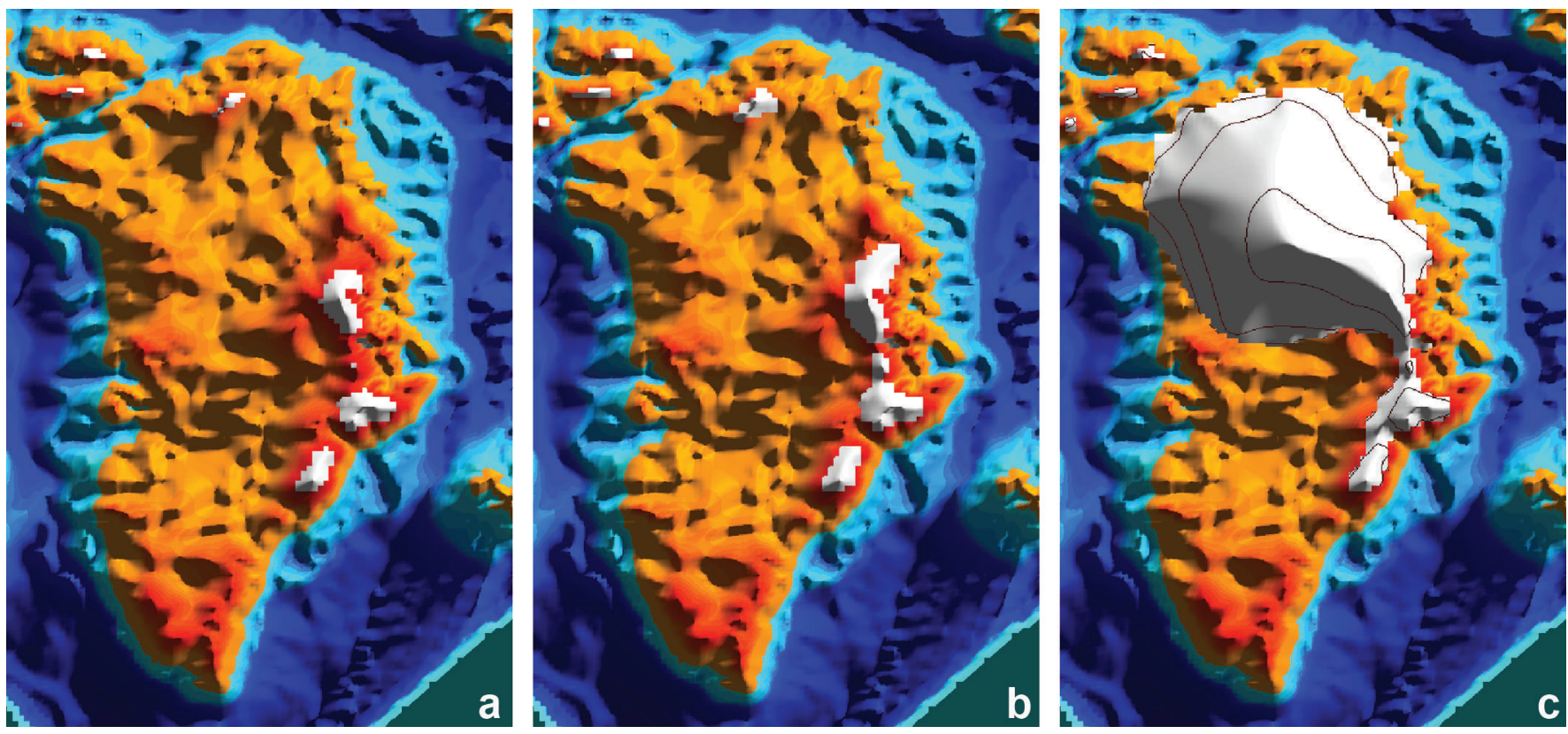

Fig. 6. The GIS configuration for the three experiments in the KK snapshot (Table 2): (a) KK1, (b) KK4 and (c) KK5. The three contours mark 1500,2000 and $2500 \mathrm{~m}$ elevation. Only when lowering $\Delta T_{\text {July }}$ to $2^{\circ} \mathrm{C}$ (c) does a considerable amount of ice remain. 

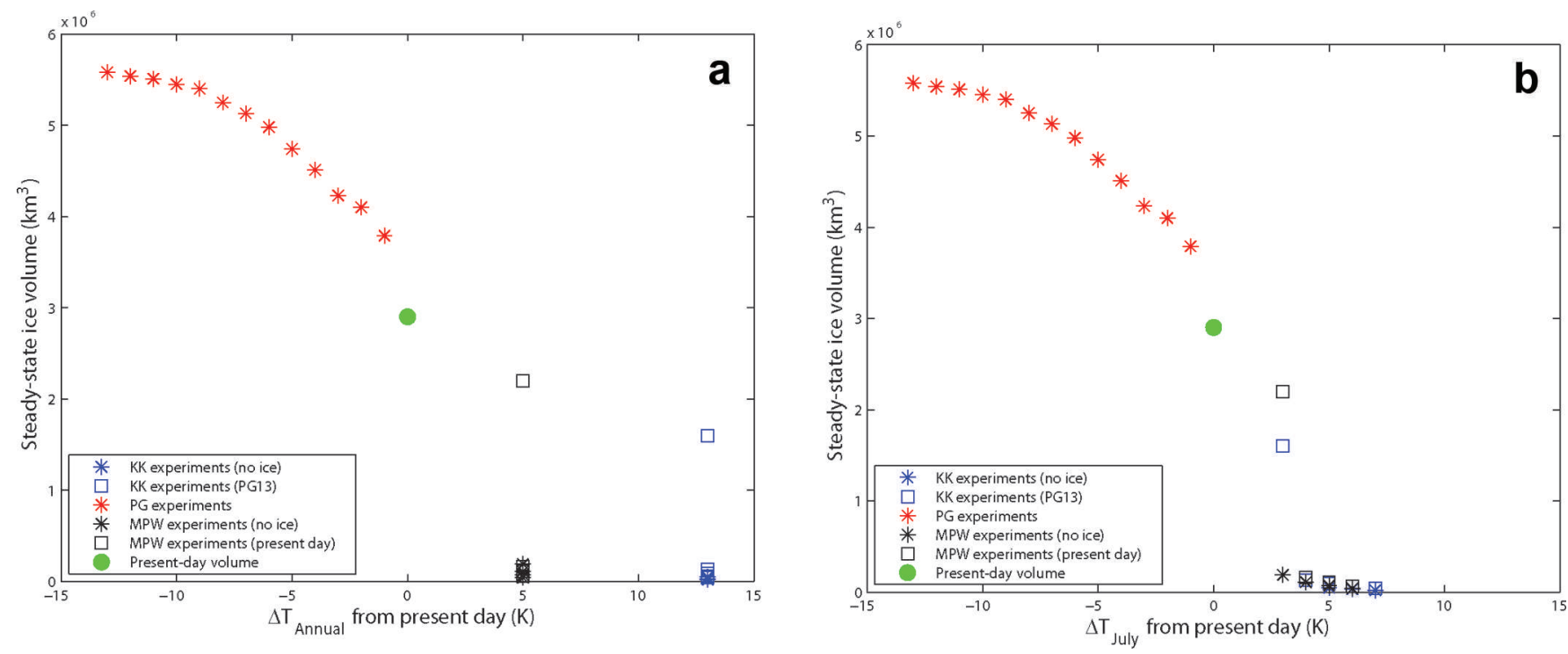

Fig. 7. Steady-state ice volume plotted against mean annual temperature (a) and mean July temperature (b) used in the experiments. The influence of the initial configuration of the ice sheet is clearly seen in the MPW experiments.

across the shelf due to the open ocean than in our experiments. The ice sheets in our experiments thus designate the upper limit of ice extent and advance rate. This is also suggested by the fact that even during the Last Glacial Maximum, when the temperature at the Greenland Icecore Project (GRIP) site was $23^{\circ} \mathrm{C}$ lower than at present (Dahl-Jensen and others, 1998), the ice sheet did not extend significantly beyond the present coastline at Scoresby Sund, while possibly extending further out in southeast Greenland (Solheim and others, 1998).

\section{Kap København}

The large ice sheet of PG13 disintegrates completely, leaving only small local ice caps in experiments KK1-KK4, while a large ice sheet still covers northern Greenland in experiment KK5 (Fig. 6). The ice sheet has retreated on land in all five experiments within the first 2000 model-years because of the drastic change in climate between the PG13 and $\mathrm{KK}$ experiments: $\Delta T_{\text {Annual }}$ increases $26^{\circ} \mathrm{C}$ from $-13^{\circ} \mathrm{C}$ to $13^{\circ} \mathrm{C}$, and $\Delta T_{\text {July }}$ increases $18^{\circ} \mathrm{C}$ from $-13^{\circ} \mathrm{C}$ to $5^{\circ} \mathrm{C}$. The mass balance in these snapshots is very negative in the shelf areas and at sea level in general.

During the climatic optimum of the Kap København Formation, a $13^{\circ} \mathrm{C}$ increase in mean annual temperature and a $7^{\circ} \mathrm{C}$ increase in July temperature are suggested by Funder and others (2001). These temperature anomalies are input to $K K 3$, and the result of this experiment as well as KK1, KK2 and KK4 corresponds well with the warm, ice-free Greenland described by Funder and others (2001). Only in KK5, with $\Delta T_{\text {July }}=3^{\circ} \mathrm{C}$ which is considerably lower than what is suggested by Funder and others (2001), does a large mass of ice remain.

The values of $\Delta T_{\text {Annual }}$ and $\Delta T_{\text {July }}$ are added uniformly to the parameterization of present-day temperatures, meaning that we do not take into account a possible polar amplification of temperature. This might be important in the KK experiments in which $\Delta T_{\text {Annual }}$ and $\Delta T_{\text {July }}$ are obtained from a site in northernmost Greenland. All five KK experiments show an ice-free southern Greenland. It therefore seems likely that Greenland was ice-free during this climatic optimum.
The MPW and KK snapshots show that build-up of the ice sheet always starts in the coastal mountains of East Greenland and that when climate becomes sufficiently warm the ice sheet retreats to the these mountains if started from a present-day-like ice-sheet geometry.

\section{CONCLUSIONS}

We have investigated steady-state ice-sheet configurations of the GIS during three extreme periods of the Pliocene to early Pleistocene by applying the 3-D, thermomechanical iceflow model PISM constrained by geological observations. Figure 7 and Table 2 clearly demonstrate the wide range of possible ice volumes resulting from the different conditions during the studied geological time interval.

Only very small amounts of ice develop in the high coastal mountains of East Greenland in the MPW experiments, where we use values at the middle to higher end of the range of the summer temperature increase predicted by Jiang and others (2005), but at the lower end of what is predicted in the simulations by Haywood and Valdes (2004). The experiments show that development of the ice in the coastal mountains of East Greenland is similar to the results of Lunt and others (2009), but we find that both the extent and the volume of the ice are much smaller than in that study. Furthermore, our results point to a significantly smaller ice volume than that of the PRISM2 reconstruction (Dowsett and others, 1999). To obtain a larger ice sheet, smaller temperature increases must be applied. Alternatively, the experiments must start from a considerable ice sheet that may have existed before the MidPliocene Warmth, but even then a significant amount of ice only remains at low $\Delta T_{\text {July. }}$. Based on our experiments, we find that no coherent ice sheet is likely to have existed in Greenland during the Mid-Pliocene Warm period.

Ice flows onto the continental shelf in the PG snapshot, and the calving line is set at the shelf break. Before the ice sheet reaches the calving line and is forced to have a specific geometry, the model predicts bulges in many of the same places as the present-day continental shelf. This indicates that the large-scale features of the inland topography control the flow of the ice onto the shelf areas. Due to the lack of 
open water in the parameterization and the use of the present-day continental shelf, the ice extent becomes too large in our experiments. However, under conditions close to the present day, Figure 4 identifies the locations where the GIS most likely will advance onto the shelf in the case of lower sea level.

During the climate optimum of the Kap København Formation, only small, local ice caps are thought to have existed in Greenland (Funder and others, 2001). Using Funder and others' (2001) values of temperature increase, we indeed obtain an almost ice-free Greenland where only local ice caps exist in the high coastal mountains. This result seems robust, as a considerable lowering of summer temperature in the model is needed for a large ice mass to remain.

The great variability of the GIS during the Pliocene to early Pleistocene is clear from Figure 7 and is illustrated particularly by the PG and KK snapshots. This underlines that the vastly different ice-sheet geometries are important to include in studies of the climate during this period. Our results show that the GIS did not exist throughout the Pliocene to early Pleistocene and that even interglacial conditions during the late Pliocene to early Pleistocene climate deterioration caused melting of the GIS as suggested by Funder and others (2001). The forested central southern Greenland that Willerslev and others (2007) found had existed 'within the past million years' may thus have been a reality several times during the Pliocene to early Pleistocene, for instance during the Kap København climate optimum at 2.4 Ma.

\section{ACKNOWLEDGEMENTS}

This study is a part of the project Mountain building and IceSheet Stability in GREENland (Miss Green) which is funded by the Commission for Scientific Research in Greenland as part of the International Polar Year activities. We thank D. Dahl-Jensen for her help during the writing process, and S. Funder for fruitful discussions. We commemorate Niels Reeh as a source of great inspiration. We also thank the PISM group for model help and support.

\section{REFERENCES}

Bennike, O. 1990. The Kap København Formation: stratigraphy and palaeobotany of a Plio-Pleistocene sequence in Peary Land, North Greenland. Medd. Grønl. Geosci. 23.

Bennike, O., K.L. Knudsen, N. Abrahamsen, J. Böcher, H. Cremer and B. Wagner. 2010. Early Pleistocene sediments on Store Koldewey, northeast Greenland. Boreas, 39(3), 603-619.

Bueler, E. and J. Brown. 2009. Shallow shelf approximation as a 'sliding law' in a thermomechanically coupled ice sheet model. J. Geophys. Res., 114(F3), F03008. (10.1029/2008JF001179.)

Bueler, E., C.S. Lingle and J. Brown. 2007. Fast computation of a viscoelastic deformable Earth model for ice-sheet simulations. Ann. Glaciol., 46, 97-105.

Calanca, P., H. Gilgen, S. Ekholm and A. Ohmura. 2000. Gridded temperature and accumulation distributions for Greenland for use in cryospheric models. Ann. Glaciol., 31, 118-120.

Clausen, L. 1998. The Southeast Greenland glaciated margin: 3D stratal architecture of shelf and deep sea. In Stoker, M.S., D. Evans and A. Cramp, eds. Geological processes on continental margins: sedimentation, mass-wasting and stability. London, Geological Society of London, 173-203. (Special Publication 129.)

Dahl-Jensen, D. and 6 others. 1998. Past temperatures directly from the Greenland ice sheet. Science, 282(5387), 268-271.
Dowsett, H. and 8 others. 1994. Joint investigations of the Middle Pliocene climate I: PRISM paleoenvironmental reconstructions. Global Planet. Change, 9(3-4), 169-195.

Dowsett, H.J. and 6 others. 1999. Middle Pliocene paleoenvironmental reconstruction: PRISM2. USGS Open File Rep. 99-535.

Dowsett, H. and 9 others. 2010. The PRISM3D paleoenvironmental reconstruction. Stratigraphy, 7(2-3), 123-139.

Eldrett, J.S., D.R. Greenwood, I.C. Harding and M. Huber. 2009. Increased seasonality through the Eocene to Oligocene transition in northern high latitudes. Nature, 459(7249), 969-974.

England, J., N. Atkinson, J. Bednarski, A.S. Dyke, D.A. Hodgson and C. Ó Cofaigh. 2006. The Innuitian ice sheet: configuration, dynamics and chronology. Quat. Sci. Rev., 25(7-8), 689-703.

Fowler, A.C. and D.A. Larson. 1980. On the flow of polythermal glaciers. II. Surface wave analysis. Proc. R. Soc. London, Ser. A, 370(1741), 155-171.

Funder, S., O. Benniker, J. Böcher, C. Israelson, K.S. Petersen and L.A. Símonarson. 2001. Late Pliocene Greenland - the Kap København Formation in North Greenland. Bull. Geol. Soc. Den., 48(2), 117-134.

Hambrey, M.J., P.J. Barrett, W.U. Ehrmann and B. Larsen. 1992. Cenozoic sedimentary processes on the Antarctic continental margin and the record from deep drilling. Z. Geomorphol., Suppl. 86, 77-103.

Haywood, A.M. and P.J. Valdes. 2004. Modelling Pliocene warmth: contribution of atmosphere, oceans and cryosphere. Earth Planet. Sci. Lett., 218(3-4), 363-377.

Haywood, A.M., H.J. Dowsett, P.J. Valdes, D.J. Lunt, J.E. Francis and B.W. Sellwood. 2009. Introduction: Pliocene climate, processes and problems. Philos. Trans. R. Soc. London, Ser. A, 367(1886), $3-17$.

Hill, D.J., A.M. Haywood, R.C.A. Hindmarsh and P.J. Valdes. 2008. Characterizing ice sheets during the Pliocene: evidence from data and models. In Williams, M., A.M. Haywood, F.J. Gregory and D.N. Schmidt, eds. Deep-time perspectives on climate change: marrying the signal from computer models and biological proxies. London, Geological Society of London, 517-538.

Hutter, K. 1983. Theoretical glaciology; material science of ice and the mechanics of glaciers and ice sheets. Dordrecht, etc., D. Reidel Publishing Co./Tokyo, Terra Scientific Publishing Co.

Jakobsson, M. and 7 others. 2008. An improved bathymetric portrayal of the Arctic Ocean: implications for ocean modeling and geological, geophysical and oceanographic analyses. Geophys. Res. Lett., 35(7), L07602. (10.1029/2008GL033520.)

Jansen, E. and 15 others. 2007. Paleoclimate. In Solomon, S. and 7 others, eds. Climate change 2007: the physical science basis. Contribution of Working Group I to the Fourth Assessment Report of the Intergovernmental Panel on Climate Change. Cambridge, etc., Cambridge University Press, 433-497.

Japsen, P., J.M. Bonow, P.F. Green, J.A. Chalmers and K. LidmarBergström. 2006. Elevated, passive continental margins: longterm highs or Neogene uplifts? New evidence from West Greenland. Earth Planet. Sci. Lett., 248(1-2), 330-339.

Jiang, D., H. Wang, Z. Ding, X. Lang and H. Drange. 2005. Modeling the middle Pliocene climate with a global atmospheric general circulation model. J. Geophys. Res., 110(D14), D14107. (10.1029/2004JD005639.)

Kleiven, H.F., E. Jansen, T. Fronwal and T.M. Smith. 2002. Intensification of Northern Hemisphere glaciations in the circum Atlantic region (3.5-2.4 Ma): ice-rafted detritus evidence. Palaeogeogr., Palaeoclimatol., Palaeoecol., 184(3-4), 213-223.

Larsen, H.C. and 6 others. 1994. Seven million years of glaciation in Greenland. Science, 264(5161), 952-955.

Letréguilly, A., P. Huybrechts and N. Reeh. 1991. Steady-state characteristics of the Greenland ice sheet under different climates. J. Glaciol., 37(125), 149-157.

Lingle, C.S. and J.A. Clark. 1985. A numerical model of interactions between a marine ice sheet and the solid Earth: application to a West Antarctic ice stream. J. Geophys. Res., 90(C1), 1100-1114. 
Lunt, D.J., G.L. Foster, A.M. Haywood and E.J. Stone. 2008. Late Pliocene Greenland glaciation controlled by a decline in atmospheric $\mathrm{CO}_{2}$ levels. Nature, 454(7208), 1102-1105.

Lunt, D.J., A.M. Haywood, G.L. Foster and E.J. Stone. 2009. The Arctic cryosphere in the Mid-Pliocene and the future. Philos. Trans. R. Soc. London, Ser. A, 367(1886), 49-67.

Lunt, D.J., A.M. Haywood, G.A. Schmidt, U. Salzmann, P.J. Valdes and H.J. Dowsett. 2010. Earth system sensitivity inferred from Pliocene modelling and data. Nature Geosci., 3(1), 60-64.

Lykke-Andersen, H. 1998. Neogene-Quaternary depositional history of the East Greenland shelf in the vicinity of Leg 152 shelf sites. In Saunders, A.D., H.C. Larsen, P.D. Clift and S.W. Wise, eds. Proceedings of the Ocean Drilling Program, Scientific Results, Vol. 152. College Station, TX, Texas A\&M University. Ocean Drilling Program, 29-38.

Marsiat, I. 1994. Simulation of the Northern Hemisphere continental ice sheets over the last glacial-interglacial cycle: experiments with a latitude-longitude vertically integrated ice sheet model coupled to a zonally averaged climate model. Palaeoclimates, 1(1), 59-98.

Miller, G.H. and 21 others. 2010. Temperature and precipitation history of the Arctic. Quat. Sci. Rev., 29(15-16), 1679-1715.

Mudelsee, M. and M.E. Raymo. 2005. Slow dynamics of the Northern Hemisphere glaciation. Paleoceanography, 20(4), PA4022. (10.1029/2005PA001153.)

Nielsen, T. and 8 others. 2005. A comparison of the NW European glaciated margin with other glaciated margins. Mar. Petrol. Geol., 22(9-10), 1149-1183.
North Greenland Ice Core Project (NorthGRIP) members. 2004. High-resolution record of Northern Hemisphere climate extending into the last interglacial period. Nature, 431(7005), 147-151.

Reeh, N. 1991. Parameterization of melt rate and surface temperature on the Greenland ice sheet. Polarforschung, 59(3), 113-128.

Salzmann, U., A.M. Haywood, D.J. Lunt, P.J. Valdes and D.J. Hill. 2008. A new global biome reconstruction and data-model comparison for the Middle Pliocene. Global Ecol. Biogeogr. 17(3), 432-447.

Sohl, L.E. and 6 others. 2009. PRISM3/GISS topographic reconstruction. Reston, VA, US Geological Survey. (USGS Data Series 419.)

Solheim, A. and 7 others. 1998. Late Cenozoic seismic stratigraphy and glacial geological development of the East Greenland and Svalbard-Barents Sea continental margins. Quat. Sci. Rev., 17(1-3), 155-184.

Stokes, C.R. and C.D. Clark. 2001. Palaeo-ice streams. Quat. Sci. Rev., 20(13), 1437-1457.

Thiede, J. and 7 others. 1998. Late Cenozoic history of the polar North Atlantic: results from ocean drilling. Quat. Sci. Rev. 17(1-3), 185-208.

Willerslev, E. and 29 others. 2007. Ancient biomolecules from deep ice cores reveal a forested southern Greenland. Science, 317(5834), 111-114

Zweck, C. and P. Huybrechts. 2005. Modeling of the northern hemisphere ice sheets during the last glacial cycle and glaciological sensitivity. J. Geophys. Res., 110(D7), D07103. (10.1029/2004JD005489.) 